This document is the accepted manuscript version of the following article: De11'oro,

M., Mataruga, M., Sass-Klaassen, U., \& Fonti, P. (2020). Climate change threatens on endangered relict Serbian spruce. Dendrochronologia, 59, 125651 (8 pp.).

https://doi .org/10.1016/j.dendro.2019.125651

This manuscript version is made available under the CC-BY-NC-ND 4.0

1icense http://creativecommons.org/1icenses/by-nc-nd/4.0/

\title{
Climate change threatens on endangered relict Serbian spruce
}

2

\section{Matteo Dell'Oro ${ }^{1,2^{*}}$; Milan Mataruga ${ }^{3}$; Ute Sass-Klaassen ${ }^{1}$; Patrick Fonti}

\author{
${ }^{1}$ Forest Ecology and Forest Management Group, Wageningen University, Wageningen, Netherlands \\ ${ }^{2}$ Swiss Federal Institute for Forest Snow and Landscape Research WSL, Birmensdorf, Switzerland \\ ${ }^{3}$ Faculty of forestry, University of Banja Luka. Bosnia and Herzegovina
}

*Corresponding author: matte.dello@hotmail.it

\begin{abstract}
:
The increase in length and severity of drought events predicted for Southeast Europe are expected to engender important changes to its remaining native forest. To take informed management decision promoting their conservation, it is important to better understand their responses to environmental disturbances.
\end{abstract}

In this study we analyze tree-ring growth responses over a network of 15 sites of Serbian spruce (Picea omorika), an endemic relict conifer species of the Balkan region - with a natural range restricted to the canyon of the Drina river at the border between Serbia and Bosnia Herzegovina - and that has already shown signs of decline and dieback likely induced by climate change.

Tree-ring analyses spanning the common period from 1974 to 2016 have proved a strong growth reduction in the last 30 years and highlighted a negative growth response to summer drought, although the strength of the response differed among individuals, where younger trees and trees growing at lower altitude suffered more from drought.

Management practice, such as inter- and intra-specific thinning to reduce competition for water resources and enhance survival of seedlings, together with assisted natural regeneration and migration to more suitable habitats are recommended for the conservation of this relict species. The measures are even more necessary considering that this species is more vulnerable than others due to its weak capacity to naturally regenerate and compete. 
The Mediterranean Basin represents one of the most important hotspots of biodiversity on Earth (Médail and Quézel, 1999; Fady-Welterlen, 2005). However, a rapid economic development, an increasing human population and climate-change-induced environmental disturbances are creating unprecedented pressures on the natural resources in the area. The Balkan region, hosting 7500 plant species, of which one third is endemic (Aleksić and Geburek, 2014), including some relict tree populations, does not escape this threat. General increase in temperature and decrease in precipitation together with the increased frequency and severity of drought events represent a new threat for many tree species on the Balkan. Moreover, this region is expected to undergo highest impacts in Europe, since the frequency, length and severity of droughts events are expected to be stronger (Ivetić and Devetaković, 2016) in areas already coping with water scarcity (Laušević et al., 2008). According to the IPCC (Intergovernmental Panel on Climate Change) scenario for Bosnia and Herzegovina mean annual temperature will increase by 2,4 to $4{ }^{\circ} \mathrm{C}$ by the end of this century with a 0 to $-30 \%$ decline in precipitation regimes compared to the period 1961-1990 (UNDP , 2016).

These changes in climate are expected to strongly affect native forest ecosystems and first evidences of such changes have already been already reported since the middle of the $19^{\text {th }}$ century (Lindner et al., 2010). More recently, signs of reduced growth and dieback have been mainly observed in coniferous tree species as spruce and pine (Ivetić and Aleksić, 2016). These diebacks are often related to insect calamities, such as bark beetles, which are suggested to be triggered by the ongoing climate change (e.g.; Allen et al., 2010). It is in particular suggested, that drought periods, such the recent summer droughts in 2015 and 2018, lead to a physiological weakening and enhanced susceptibility to disease and pests (Ivetić and Aleksić, 2016). Yet, little is known about the long-term response to changing climate and climate extremes of relict and endangered native forest trees species of in the Balkan region (Aleksić and Geburek, 2014).

Serbian spruce (Picea omorika) is one of these endemic and endangered relict conifer species. Its natural range is restricted around the course of the Drina river, between Western Serbia and Eastern Bosnia and Herzegovina (Ballian et al., 2016; Ivetić and Aleksić, 2016). Its actual habitat is restricted to hardly accessible steep and rocky slopes mostly facing north, east and west on lime stone and serpentine bedrock at an elevation ranging from 800 to $1500 \mathrm{~m}$ (Wardle, 1956; Ballian et al., 2016) characterized by a continental climate with cold and snowy winter and by hot and dry summers. Few authors who have morphologically and ecologically described the species (Ostojić and Dinić, 2009; Nikolić et al., 2015; Ballian et al., 2016; Ivetić and Aleksić, 2016) characterised it as very heliophile and ideally requiring at least mean annual temperature between 4 and $6{ }^{\circ} \mathrm{C}$ and yearly precipitation around $1000 \mathrm{~mm}$. Due to anthropogenic factors such as forest clearing or wildfires, together with poor competition capacity, physiological stress to global warming and a higher susceptibility to disease, have strongly contributed to fragmentate the habitat of the species. For these reasons, Serbian spruce has been officially listed on the red list of threatened species (Mataruga et al., 2011; 
Aleksić and Geburek, 2014; IUCN, 2018). In the past few years Serbian spruce has also been in the focus of several investigations, mostly genetic, oriented at clarifying the available genetic information and for promoting its conservation (Ballian et al., 2006; Nasri et al., 2008; Aleksić et al., 2009; Aleksić and Geburek, 2014). In fact, Serbian spruce can for example hybridize with Sitka spruces (Picea sitchensis $\mathrm{x}$ omorika) and display better juvenile frost resistance and vigour at poor sites (Ivetić and Aleksić, 2016). Current conservation measures include both an assisted natural regeneration by removal of competitors to enhance seedlings survival, and an assisted migration.

Conservation measures would much benefit by complementary knowledge of Serbian spruce's susceptibility to future climate conditions. Since these native forests have hardly been considered for an active management, there is very little information on the growth ecology of the species. In this study we use treering width measurements to assess climate-growth relationships of Serbian spruce at 15 sites along its native range along the Drina river canyon with the aim of i) characterizing the long-term growth trend of populations of different age, ii) identifying the main climatic drivers limiting growth within its native range, iii) quantifying the vulnerability to extreme (drought) events among ages and locations.

\section{Materials and methods}

\section{Study area, site locations and sampling}

This study has been performed in the native area of occurrence of Serbian spruce (Picea omorika), at the border between Serbia and Bosnia and Herzegovina (Fig. 1a). A total of 17 unmanaged stands were selected across the native area and on different elevation (from 845 to $1541 \mathrm{~m}$ asl; Table 1). The climate of the area is characterized by a continental climate characterized by mean annual temperature of $7-8{ }^{\circ} \mathrm{C}$ and well distributed precipitation totaling $\sim 950 \mathrm{~mm}$ (Fig. 1b). Over the last 100 years an increase of the annual average temperature is observed while precipitation was slightly decreasing (Fig. 1C).

Sampling has been performed from June to August, 2018 on 11 to 35 dominant and healthy trees per sites. In total 325 wood cores were collected at $1.3 \mathrm{~m}$ stem height using an increment borer. Cores were labelled and stored in plastic straws and delivered to the Swiss Federal Institute for Forest, Snow and Landscape Research WSL for further processing (i.e. surface preparation to increase the tree rings visibility and measurement the annual increments). After this, only 15 out of 17 population were considered in further analyses since sites 9 and 17 (Plistina and Bozurevac) were discarded due to insufficient number of replicates. 
Tree-ring width (TRW) was measured on each collected core with a Lintab digital positioning table connected to the TSAP-Win software (both RinntechH, 2010). Time series were first visually cross-dated and its quality checked with the software Cofecha (Holmes, 1983). Site chronologies have been successively calculated by removing non-climatic signal using a 10-year spline function applied to each time series to only maintain high frequency variation. The obtained ring-width indices (RWI) have been averaged into a chronology for each site.

To assess the common variation among individual detrended time-series at each site, we calculated, i) the Gleichläufigkeit (Glk; which represents the percentage of common signs of year-to-year growth change between series, Eckstein and Bauch, 1969), ii) the inter-series correlation (calculated as the average between each series and a master chronology), and iii) the mean correlation between trees ( $r_{\text {bar }}$, calculated as the mean Pearson correlation coefficient of the tree-ring width time series at a site). Chronology building and quality assessment have been performed using the R package $d p / R$ (Bunn, 2008). Additionally, the mean ring width and tree age (by considering the pith offsets) were also determined.

\section{Assessing growth responses to climate}

To identify the main climatic drivers of tree growth we assessed climate response analyses using the $R(R$ Core Team, 2018) package Treeclim (Biondi and Waikul, 2004; Zang and Biondi, 2015) by applying a bootstrapped response function where the RWI chronologies are used as the dependent variable and the monthly climatic data are the independent variables. The analyses only considered the period with sufficient replicates, i.e. for the period 1974 to 2016.

As climatic variable we considered the monthly mean temperature, precipitation sum and the standardize precipitation evapotranspiration index (SPEI) with a time-scale of three months. SPEI is a multiscale drought index combining temperature and precipitation data, based on monthly water balances (Vicente-Serrano et al., 2010). Temperature and precipitation were retrieved from the high-spatially resolved (30 arc sec) data from CHELSA (Karger et al., 2017) and extended prior to 1979 (extended-CHELSA) by applying a transfer function with the lower resolved Climatic Research Unit data (CRU, 0.5 degree; Harris et al., 2014) of the corresponding grid cell. Site coordinates were assessed by averaging the longitude and latitude of the trees belonging to the same population. The SPEI was calculated with the R package SPEI on the length of three months (SPEI3) using the previously extracted CHELSA temperature and precipitation data. For the calculation, we included only the monthly climate variables from June of the previous year to September of the current year as well as the monthly average from March to May and from June to August. The significance of the correlation coefficients was calculated by assessing the $95 \%$ confidence levels based on 1000 random samplings with replacements. 
132 Analysis of growth responses to extreme years

133 Growth responses to extreme drought events were assessed by comparing the changes in growth during the 134 extreme events and in the following years. Trees were categorised in three classes according to elevation 135 (LOW $=800$ to $1000 \mathrm{~m}$ asl., MIDDLE $=1000$ to $1200 \mathrm{~m}$ asl., and HIGH = 1200 to $1500 \mathrm{~m}$ asl.) and age: (YOUNG $136<80$ years, MEDIUM $=81$ to 160 years, and OLD $>161$ years). Negative pointer years were selected when at least $50 \%$ of trees featured a tree-ring width index decline of at least $40 \%$ compared to the average previous five years using the R package pointRes (Van der Maaten-Theunissen et al., 2015). The response to extreme years was assessed using the resilience parameters of Lloret et al., (2011), as:

- $\quad$ Resistance $=D r / P r e D r$

- $\quad$ Recovery $=$ PostDr/Dr

- $\quad$ Resilience $=$ PostDr/PreDr

where PreDr is the average tree-RWI five years before the drought year, $D r$ the tree-RWI in the drought year and PostDr the average tree-RWI in the five years after the drought year.

\section{Results}

\section{Growth characteristics}

The 15 tree-ring width chronologies indicate that large differences in age and growth rates exist between sites (Fig. 2a). The stand age ranged from $40-55(1,2,3,7,8,10,12,15,16)$, to 120-150 years old stands (5 and 6$)$. Few sites showed quite heterogeneity in tree age $(4,11,13,14$, Table 1$)$. The average annual radial growth ranged from a minimum of $0.92 \mathrm{~mm}$ (6) to a maximum of $2.27 \mathrm{~mm}$ (15) (Table 2) and in general it was higher for younger stands (e.g.; 1, 3, 15, 16) than older stands (e.g.; 4, 5, 6, 11). The age-aligned regional growth curves indicated that Serbian spruce generally reached a maximum growth rates at around 20 years (Fig. 2b). Although few young $(10,15,16)$ and old stands $(4,6,11)$ clearly showed higher and respectively lower maximum growth rates than average, all young stand seemed to experience a steeper and more persistent growth decline than older ones. However, this difference could be related to the establishment after a forest fire, when light availability in the beginning is high and after 20 years competition leads to strong growth declines. Indeed, Fukarek (1951) mentions the occurrrnece of numerous forest fire in 19461947 decimating the Serbian spruce populations. In older stands, the situation is most likely different since we see a much slower juvenile growth indicating establishment e.g. in smaller gaps.

The similarity in growth patterns of trees within each site is consistently high. The Gleichläufigkeit values are $>61 \%$, denoting strong common signs of year-to-year growth change between the series of the same sites. 
Moreover, both the inter-series correlation and the $R_{\text {bar }}$ varied little among sites and showed strong values, ranging between 0.47 and 0.69 for the inter-series correlation and between 0.36 and 0.63 for the $R_{b a r}$. Sites which are geographically close and/or belong to the same altitudinal band showed similar growth (see Fig. 3). The lowest correlation ( $r=0.12)$ was found between the young low-elevation stand at site 5 and the old high-elevation stand at site 8.

\section{Climate-growth responses}

The climate-growth analysis over the common period from 1974 to 2016 indicated that Serbian spruce growth is strongly related to summer conditions (Fig. 4a). The growth responses to precipitation and SPEI were similarly strong. Correlation with SPEI showed higher absolute coefficients compared to correlation with temperature, which is only significant for the summer (JJA). All the sites have a significant positive correlation with SPEI3 in August (average drought index June, July and August) and precipitation in summer, with coefficients values also above $0.6(p<0.05)$, meaning that smaller rings are formed during drier conditions. The composite chronology showed a positive, but non-significant relation with temperature in the early growing season and a negative significant relation with summer mean temperature.

The climate-growth correlation on a 25-years moving window (Fig. 4b) indicated an increase of the SPEI3 correlation of September (water availability in July, August and September), which is significant from the 1980ies until present. This correlation was also highly significant at the beginning of the last century, then it started to decrease around the 1930ies and 40ies, to increase again in the 1980ies. This means that trees seem to have a longer growing season but at the same time are experiencing more drought during summer. Also, the increase in correlation coefficient in April and May indicates the trees benefit, in terms of growth, from the higher temperature during the first part of the growing season. The same conclusions can be drawn looking at the temperature-growth correlation on the 25-years moving window, where an increase in the negative influence of summer months appears for the last 50 years, as well as an increase in the negative influence of May. Regarding the precipitation-growth correlation, positive and significance values for spring and summer months indicate that growth is higher when precipitation regime are high.

All study sites show positive and significant correlation with SPEI3 in August, which represents the strongest climate signal obtained in the results, considering the sites singularly (Fig. 4c). Regarding the altitude, it is not possible to establish a clear climate-growth correlation gradient along the elevation, since population in middle of the altitude orders misshape the decreasing gradient. Still, in general sites at lower elevations (1, $3,15,16)$ tend to show a stronger relationship with SPEI3, as well as with temperature, in comparison to sites at more elevated sites $(4,10,13,14)$. Considering the single sites, 5 and 11 show lower - though still significant - positive relationship with SPEI3, meaning that they seem to be less susceptible to summer 
drought in comparison to other low and middle elevation sites. Site 5 is the northernmost one, while 11 is the is the furthest southwest-located.

\section{Resilience to extreme events}

When considering all the trees, only 2012 was revealed as an extreme negative growth year, in which the majority of trees featured at least a 40\% growth decline. However, Fig $1 \mathrm{c}$ and literature (Hodzic et al., 2011) suggest other extreme years $(1990,2000,2003)$ in the Bosnia and Herzegovina climate's history. If computing the analysis on trees grouped into three distinct elevation groups, the drought year 2012 clearly emerged as a negative pointer year for the low-elevation sites. Although according to Van der Maaten-Theunissen et al. (2015) the year 2012 cannot be strictly considered a pointer year for middle and high elevations trees, Llorets resilience components (Llorets et al. 2011) calculated among elevation and age classes indicated the presence of significant differences among groups (Kruskal-Wallis, $p<0.05$ ) (Fig. 5). In general, the resistance of low elevation trees to the 2012 dry summer conditions were significantly lower than that of middle and high elevation trees (both $\mathrm{p}<0.05$ ). However, resistance to drought did not significantly differed between middle and high elevation trees $(p=0.247)$. These analyses also indicate that the resistance of younger trees was significantly lower than for more aged trees. Significance differences have also been observed regarding the recovery, specifically indicating that old trees recover slower than young trees $(p<0.05$.) However, low resistance and high recovery could also be an indication of strong plasticity.

\section{Discussion}

Serbian spruce growth - and supposedly also establishment - is closely related to short-term and long-term dynamics in climate, mainly related to water availability during summer. This relationship expressed by high correlations with precipitation and the SPEI3 in the summer from June to August was consistently found in all 15 studied relict populations. Among populations there was a tendency that Serbian spruce at lower elevation show a stronger negative growth response to summer drought in comparison to those growing at higher elevations (Fig. 4c). This elevation trend is in line with findings for the other spruce species growing in South-Eastern Europe, such as Norway spruce (Picea abies) in Serbia (Castagneri et al., 2014) as well as Pinus peuce and Pinus heldreichii in Bulgaria (Panayotov et al., 2010). Levanič et al. (2009) found that mainly increasing summer temperature deteriorates radial growth of low elevation Norway spruce in South-Eastern Europe by enhancing evapotranspiration and hence drought stress. Drought stress has, however, also been observed, although with minor impact, at high-elevation sites indicating that, despite tree growth in mountain environment is often positively related to warmer conditions, has still led to increased evapotranspiration (Jolly et al., 2005; Savva et al., 2006). 
230 The assessment of long-term variation in climate-growth relationships (Fig. 4b) proved the short-term 231 acclimation potential of Serbian spruce. Past periods with summer droughts, e.g. 1945 to 1955 (Fig. 1c \& d) 232 and consecutive wetter and cooler period until 1980, when the recent warming intiated, are reflected by synchronous stronger links or weaker dependencies on summer conditions. The fact that young populations established in the relative wetter and cooler period in the 1960ies and 70ies (Fig. 2) could indicate the regeneration potential of Serbian spruce, at least in the past. After a period with heavy droughts between 1945 and 1955 with lot of forest fires (Fukarek, 1951) the forest has recovered showing the its potential under improved climate conditions (low SPEI in the 1960ies and generally higher rainfall). However, under future conditions with increasing drought this might not be possible. The young trees showed a strong growth decline in the recent period which seems stronger than the growth decline of older trees to the dry conditions in the 1940ies and 1950ies - and which might indicate that they indeed suffered from recent climate change.

The recent period with enhanced temperature and drought frequency starting in 1980 resulted again in a stronger relationship between growth and summer conditions, comparable to the situation in the 1940ies and 50ies. The SPEI3, indicating drought intensity in the summer months (JJA) reached unprecedented low values in 1990, 2000, 2003 and especially 2012 (Fig. 1d) causing - for 2012 - strong growth depressions, specifically in young spruces and trees at low altitude (Fig. 5). However, trees in all age (but especially young trees) and elevation categories had the ability to fast recover.

Although we found differences in the climate-growth correlation between the studied sites, the environmental variables used in the analysis were not sufficient to explore specific site-related reasons beyond the explained general trends related to altitude and tree age. Low elevation sites may have indeed, a generally higher growth rate, because of the warmer conditions during the growing season, which generally favor growth in mountainous areas. But at the same time higher temperature, especially during summer can cause water shortage and hence induce drought stress at lower elevation sites. Indeed, the soil observations from the field work indicate very underdeveloped soil, probably due to the erosion process during the years. However, the extreme drought event in 2012 does not seem to have much influenced the Serbian spruce populations, since almost all the trees completely recovered in the years following the event (resilience). Also, differences in soil depth, nutrient levels, stand density, presence of other competing species are all factors which would be to consider to assess sites-specific differences.

Interestingly, site 6 showed an unusual growth trend in the past two and a half decades, which apparently is paralleling the increasing in temperature trend (Fig. 3a). This would lead to the conclusion that this site (Strugovi), may have adapted better and faster to the current climate change, relatively to the other ones. However, a better explanation of this unusual trend can be related to fire taking place in Strugovi during 1992-1993 (Mataruga et al., 2011), which, burning down a great part of the forest, may have enhanced the growth of the survived trees. In fact, as literature reports, Serbian spruce is a high shade-intolerant (Tucić 
and Stojković , 2001; Tucić et al., 2005; Ivetić and Aleksić, 2016). In particular, Tucić and Stojković (2001) reported a low additive genetic variation for plasticity in shade-avoidance traits, leading this species to predominate open sites, although its growth may be later on suppressed by other shade-tolerant species.

Overall, these results confirm that the recent changes in climate conditions - along with fires, competition and low migration rate - form a potential threat to the survival of this endangered forest species. Indeed, consequently to its small populations size and the lack of regeneration combined with the slow migration potential and speed, already constituted a broad set of threats for the conservation of the species in its natural habitat. An increased frequency of longer periods with high summer temperature in South Eastern Europe occurring during the last few decades (Ivetić and Devetaković, 2016) add a new element reducing the growth resilience of the species. Five out of seven among the greatest heat waves in the period 1961-2010 have occurred between 2000 and 2010 and summer 2012 was recorded by most regional weather station as the hottest summer since climate measurements (WMO, 2013; Sippel and Otto, 2014). The increased drought stress might likely explain the reported increased susceptibility to insect attack and fungal diseases (Ivetić and Aleksić, 2016) associated with warm and dry years.

This new threat is expected to further increase in the near future. According to local climate model, due to a combination of increasing temperature and decreasing precipitations in the next future (Ivetić and Devetaković 2016), the pressure on Serbian spruce natural distribution area is expected to increase. In additional, warmer and drier summers will even have greater repercussion, since compared to other conifer species, it is often restricted to steep, sun exposed sites with shallow soils stimulating the formation of a superficial and branched roots system (Panayotov et al., 2010; Ballian et al., 2016). Changes in climate are being faster than Serbian spruce actual capability of adapt or migrate. Considering other obstacles, such as habitat fragmentation, soil's lack of depth and nutrients, and general geography and topography, this species will face a hard time to survive in such condition (Ivetić and Devetaković, 2016; Ivetić and Aleksić, 2016). This scenario thus represents a big challenge for the conservation of this endangered relict species.

Serbian spruce has been already successfully and widely planted outside of its place of origin for both ornamentals and forestry purposes. In Estonia it has been categorized as fast growing and cold resistant species for valuable timber production, while in Southern Finland its performance was assessed as "good" and considered a potential species for forestry (Sander and Meikar, 2009) and in Czech Republic its growth rate has equaled those of the domestic Norway spruce (Kral, 2002). However, more active measures are required to promote in situ conservation. These includes assisted natural regeneration, removal of competitors to enhance seedlings survival, and preparation of new sites in less drought exposed conditions. 
Aleksić, J.M., Schueler, S., Mengl, M., Geburek, T., 2009. EST-SSRS developed for other Picea species amplify in Picea omorika and reveal high genetic variation in two natural populations. Belgian Journal of Botany. 8995.

300

Aleksić, J.M., Geburek, T., 2014. Quaternary population dynamics of an endemic conifer, Picea omorika, and their conservation implications. Conservation Genetics. 15, 87-107.

Allen, C.D., Macalady, A. K., Chenchouni, H., Bachelet, D., McDowell, N., Vennetier, M., Gonzalez, P., 2010. A global overview of drought and heat-induced tree mortality reveals emerging climate change risks for forests. Forest ecology and management. 259, 660-684.

Ballian, D., Longauer, R., Mikić, T., Paule, L., Kajba, D., Gömöry, D., 2006. Genetic structure of a rare European conifer, Serbian spruce (Picea omorika (Pančić) Purk.). Plant Syst Evol. 260, 53-63.

Ballian, D., Ravazzi, C., Caudullo, G., 2016. Picea omorika in Europe: distribution, habitat, usage and threats. European Atlas of Forest Tree Species. Publications Office of the European Union, Luxembourg. 157.

Biondi, F., Waikul, K., 2004. DENDROCLIM2002: A C++ program for statistical calibration of climate signals in tree-ring chronologies. Comput. Geosci. 30, 303-311.

Bunn, A.G., 2008. A dendrochronology program library in R (dpIR). Dendrochronologia. 26, 115-124.

Castagneri, D., Nola, P., Motta, R., Carrer, M., 2014. Summer climate variability over the last 250 years differently affected tree species radial growth in a mesic Fagus-Abies-Picea old-growth forest. Forest ecology and management. 320, 21-29.

Eckstein, D., Bauch, J., 1969. Beitrag zur Rationalisierung eines dendrochronologischen Verfahrens und zur Analyse seiner Aussagesicherheit. Forstwissenschaftliches Centralblatt. 88, 230-250.

Fady-Welterlen, B., 2005. Is there really more biodiversity in Mediterranean forest ecosystems? Taxon. 54, 905-910.

Fukarek, P.,1951: Staništa Pančićeve omorike nakon šumskih požara 1946/47. Godine, Šumarski list, br.1-2. 61-71.

Harris, I., Jones, P.D., Osborn, T.J. and Lister, D.H., 2014. Updated high-resolution grids of monthly climatic observations - the CRU TS3.10 Dataset. International Journal of Climatology. 34, 623-642.

Hodzic, S., Markovic, M., Custovic, H., 2011. Drought conditions and management strategies in Bosnia and Herzegovina. In Proceedings of the 1st Regional Workshop on Capacity Development to Support National Drought Management Policies for Eastern European Countries. 42.

Holmes, R. L., 1983. Computer-assisted quality control in tree-ring dating and measurement. Tree -Ring Bulletin. 43, $69-78$

IUCN 2018. The IUCN Red List of Threatened Species. Version 2018-2. http://www.iucnredlist.org.

Ivetić, V., Aleksić, J. M., 2016. Response of rare and endangered species Picea omorika to climate change: The need for speed. Reforesta. 1, 81-89.

Ivetić, V., Devetaković, J., 2016. Reforestation challenges in Southeast Europe facing climate change. Reforesta. 1, 178-220. 
Jolly, W.M., Dobbertin, M., Zimmermann, N.E., Reichstein, M., 2005. Divergent vegetation growth responses to the 2003 heat wave in the Swiss Alps. Geophys Res Lett 32 (Art. No. L18409).

Karger, D.N., Conrad, O., Böhner, J., Kawohl, T., Kreft, H., Soria-Auza, R.W., Kessler, M., 2017. Climatologies at high resolution for the earth's land surface areas. Scientific data. 4, 170122.

Král, D., 2002. Assessing the growth of Picea omorika [Panč.] Purkyně in the Masaryk Forest Training Forest Enterprise at Křtiny Journal of Forest science. 48, 388-398.

Laušević, R., Jones-Walters, L., Nieto, A., 2008. Climate change and biodiversity in South-East Europe impacts and action. REC, Szentendre, Hungary; ECNC, Tilburg, the Netherlands. 67.

Levanič, T., Gričar, J., Gagen, M., Jalkanen, R., Loader, N. J., McCarroll, D., Robertson, I., 2009. The climate sensitivity of Norway spruce [Picea abies (L.) Karst.] in the southeastern European Alps. Trees. 23, 169.

Lindner, M., Maroschek, M., Netherer, S., Kremer, A., Barbati, A., Garcia-Gonzalo, J., Lexer, M. J., 2010. Climate change impacts, adaptive capacity, and vulnerability of European forest ecosystems. Forest ecology and management. 259, 698-709.

Lloret, F., Keeling, E. G., Sala, A., 2011. Components of tree resilience: effects of successive low-growth episodes in old ponderosa pine forests. Oikos. 120, 1909-1920.

Mataruga, M., Isajev, V., Gardner, M., Christian, T., Thomas, P., 2011. Picea omorika. The IUCN Red List of Threatened Species.

Médail, F., Quézel, P., 1999. Biodiversity hotspots in the Mediterranean Basin: setting global conservation priorities. Cons. Biol. 13, 1510-1513.

Nasri, N., Bojovic, S., Vendramin, G. G., Fady, B., 2008. Population genetic structure of the relict Serbian spruce, Picea omorika, inferred from plastid DNA. Plant Systematics and Evolution. 271, 1-7.

Nikolić, B., Bojović, S., Marin, P. D., 2015. Variability of morpho-anatomical characteristics of the needles of Picea omorika from natural populations in Serbia. Plant Biosystems-An International Journal Dealing with all Aspects of Plant Biology. 149, 61-67.

Ostojić, D., Dinić, A., 2009.Experimental phytocoenological investigations of Serbian spruce (Picea omorika /Pančić/ Purkynĕ) natural regeneration in the national park Tara. Šumarstv., 23-35.

Panayotov, M., Bebi, P., Trouet, V., Yurukov, S., 2010. Climate signal in tree-ring chronologies of Pinus peuce and Pinus heldreichii from the Pirin Mountains in Bulgaria. Trees. 24, 479-490.

R Core Team, 2018. R: A language and environment for statistical computing. R Foundation for Statistical Computing, Vienna, Austria. URL https://www.R-project.org/.

Rinntech H, 2010. TSAP-WIN TM: Time series analysis and presentation for dendrochronology and related applications. http://www.rinntech.com, Heidelberg, Germany.

Sander, H., Meikar, T., 2009. Exotic coniferous trees in Estonian forestry after 1918. Forst und Jagdzeitung. 158.

Savva, Y., Oleksyn, J., Reich, P.B., Tjoelker, M.G., Vaganov, E.A., Modrzynski, J., 2006. Interannual growth response of Norway spruce to climate along an altitudinal gradient in the Tatra Mountains, Poland. Trees. 20, 735-746.

Sippel, S., Otto, F.E., 2014. Beyond climatological extremes-assessing how the odds of hydrometeorological extreme events in South-East Europe change in a warming climate. Climatic Change. 125, 381-398. 
378 Tucić, B., Stojković, B., 2001. Shade avoidance syndrome in Picea omorika seedlings: a growth-room 379 experiment. J Evol Biol. 14, 444-455.

380 Tucić, B., Pemac, D., Ducić, J., 2005. Life history responses to irradiance at the early seedling stage of Picea 381 omorika (Pancic) Purkynhe: adaptiveness and evolutionary limits. Acta Oecologica-International J. Ecol. 27, 382 185-195.

383 UNDP, 2016. Third national communication and second biennial update report on greenhouse gas emissions 384 of Bosnia and Herzegovina under the United Nations framework convention on climate change. UNDP, 385 Sarajevo.

386 Van der Maaten-Theunissen, M., Van der Maaten, E., Bouriaud, O., 2015. pointRes: An R package to analyze 387 pointer years and components of resilience. Dendrochronologia. 35, 34-38.

388 Vicente-Serrano, S.M., Beguería, S., López-Moreno, J.I., 2010. A multiscalar drought index sensitive to global 389 warming: the standardized precipitation evapotranspiration index. Journal of climate. 23, 1696-1718.

390 Wardle, P., 1956. Picea omorika in its natural habitat. Forestry: An International Journal of Forest 391 Research. 29, 91-117.

392 WMO (World Meteorological organization), 2013. WMO statements on the status of global climate in 2012. 393 WMO-No. 1118

394 Zang, C., Biondi, F., 2015. treeclim: an R package for the numerical calibration of proxy-climate 395 relationships. Ecography. 38, 431-436. 
Table 1: Site names, sampling depth, mean elevation, geographical location and age range.

\begin{tabular}{ccccccc}
\hline Site name & Site ID & $\begin{array}{c}\text { N of } \\
\text { trees }\end{array}$ & $\begin{array}{c}\text { Elevation } \\
{[\mathrm{m}]}\end{array}$ & $\begin{array}{c}\text { Latitude [decimal } \\
\text { degrees] }\end{array}$ & $\begin{array}{c}\text { Longitude } \\
\text { [decimal degrees] }\end{array}$ & $\begin{array}{c}\text { Age range } \\
\text { [years] }\end{array}$ \\
\hline $\begin{array}{c}\text { Perišin Gaj } \\
\text { Starogorske stijene }\end{array}$ & 1 & 29 & 948 & 43.85910 & 19.18797 & $40-57$ \\
Suvi Do & 3 & 19 & 1160 & 43.91499 & 19.16403 & $34-55$ \\
Panjak & 4 & 11 & 1290 & 43.99898 & 19.17326 & $35-55$ \\
Tisovljak & 5 & 19 & 1039 & 44.07286 & 19.09082 & $59-130$ \\
Strugovi & 6 & 17 & 974 & 43.97844 & 19.20715 & $53-243$ \\
Sarena bukva & 7 & 11 & 1061 & 44.01897 & 19.19293 & $68-128$ \\
Borov vrh & 8 & 14 & 1047 & 44.01689 & 19.20147 & $22-54$ \\
Grad & 10 & 23 & 1198 & 44.00212 & 19.22175 & $36-48$ \\
Radomišlje & 11 & 29 & 1122 & 43.46225 & 18.61265 & $36-50$ \\
Vijogor & 12 & 23 & 1121 & 43.65015 & 19.12427 & $49-180$ \\
Gostilj & 13 & 35 & 1173 & 43.85674 & 19.33362 & $42-141$ \\
Veliki stolac & 14 & 29 & 1242 & 43.92315 & 19.28002 & $44-132$ \\
Karaula Štula & 15 & 24 & 915 & 43.92976 & 19.28252 & $44-190$ \\
Vidikovac & 16 & 15 & 861 & 43.93219 & 19.27914 & $43-58$
\end{tabular}

401

Population 9 and 17 were not measured and included in the analyses due to lack of replicates

402

403

404

Table 2: Tree-ring characteristics

\begin{tabular}{cccccc}
\hline Site name & $\begin{array}{c}\text { Site } \\
\text { ID }\end{array}$ & $\begin{array}{c}\text { MRW } \\
(\mathrm{mm})\end{array}$ & Glk & $\begin{array}{c}\text { Inter-series } \\
\text { correlation }\end{array}$ & $\mathrm{R}_{\text {bar }}$ \\
\hline Perišin Gaj & 1 & 1.95 & 0.70 & 0.63 & 0.53 \\
Starogorske stijene & 2 & 1.79 & 0.67 & 0.55 & 0.42 \\
Suvi Do & 3 & 1.67 & 0.67 & 0.54 & 0.42 \\
Panjak & 4 & 1.17 & 0.72 & 0.62 & 0.50 \\
Tisovljak & 5 & 1.10 & 0.64 & 0.58 & 0.41 \\
Strugovi & 6 & 0.92 & 0.65 & 0.58 & 0.42 \\
Šarena bukva & 7 & 1.86 & 0.66 & 0.47 & 0.36 \\
Borov vrh & 8 & 1.67 & 0.71 & 0.56 & 0.55 \\
Grad & 10 & 2.14 & 0.68 & 0.66 & 0.52 \\
Radomišlje & 11 & 0.99 & 0.61 & 0.54 & 0.31 \\
Vijogor & 12 & 1.74 & 0.62 & 0.53 & 0.36 \\
Gostilj & 13 & 1.45 & 0.63 & 0.58 & 0.37 \\
Veliki stolac & 14 & 1.49 & 0.64 & 0.60 & 0.39 \\
Karaula Štula & 15 & 2.27 & 0.73 & 0.67 & 0.56 \\
Vidikovac & 16 & 2.01 & 0.77 & 0.69 & 0.63 \\
\hline
\end{tabular}

405

MRW = Mean ring width, Glk = Gleichläufigkeit, inter-series correlation (calculated on ring width index), and $\mathrm{r}_{\mathrm{bar}}=$ mean correlation 406 between trees (calculated on 10-years spline detrended timeseries, i.e. on the tree-ring width index). 


\section{FIGURES}

Fig. 1: Sites location and regional climate characteristics. a) Location of the study area and sampled sites; b) Climate diagram of the period 1901-2017; c) Average yearly temperature and precipitation of the period 1901-2017. d) Average yearly temperature and precipitation SPEI3 of the period 1901-2017. b) and c) have been obtained from averaged CHELSA-extended gridded data (Karger et al., 2017) at all 15 sites.

a)
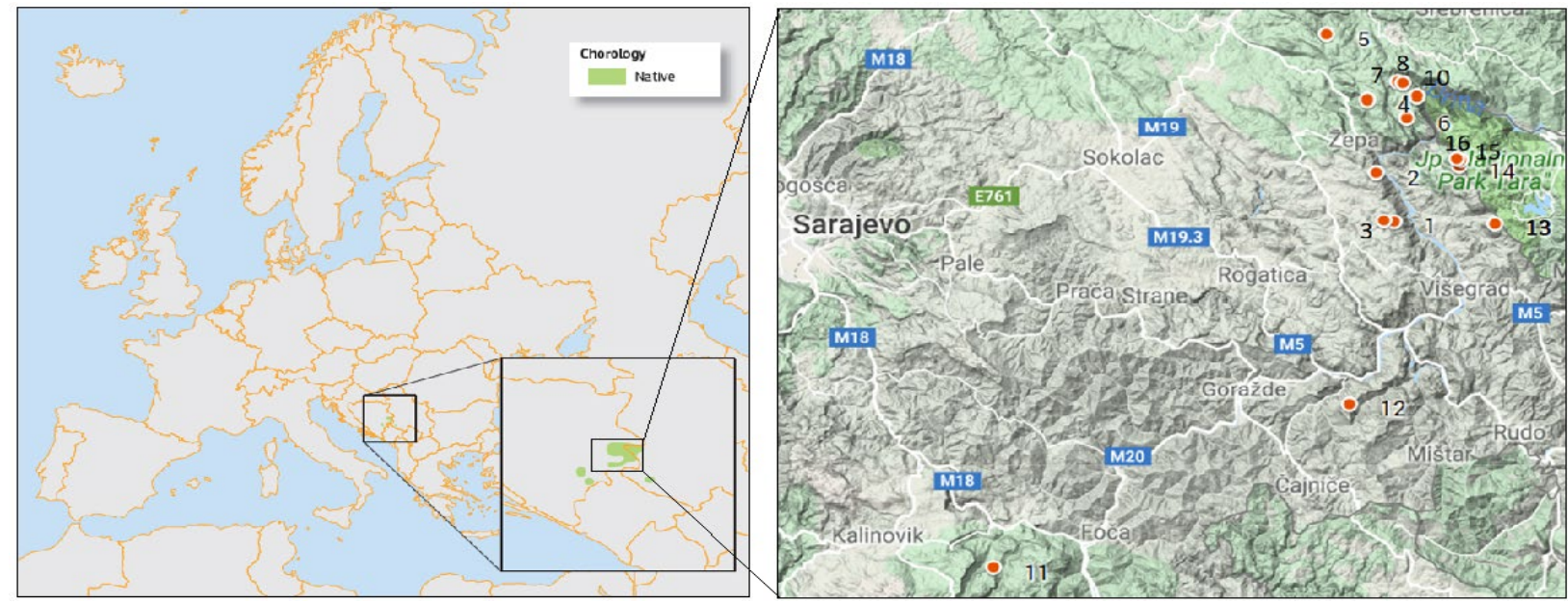

b)

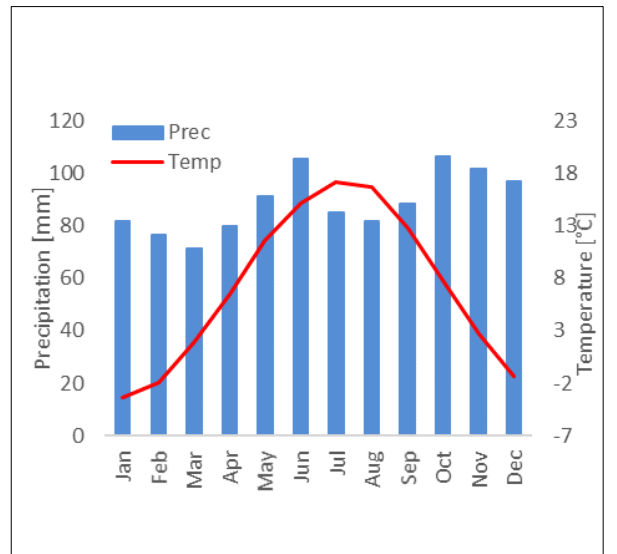

c)

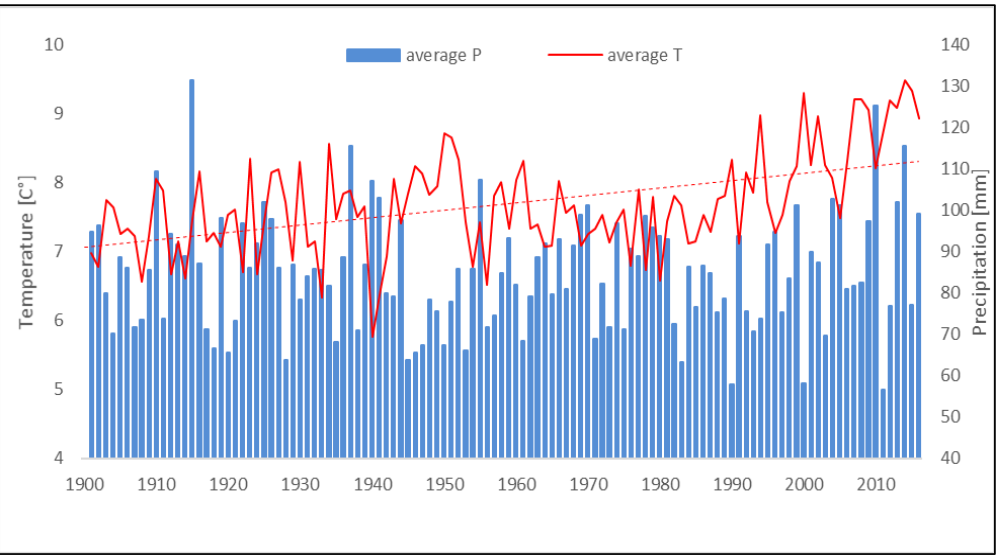

d)

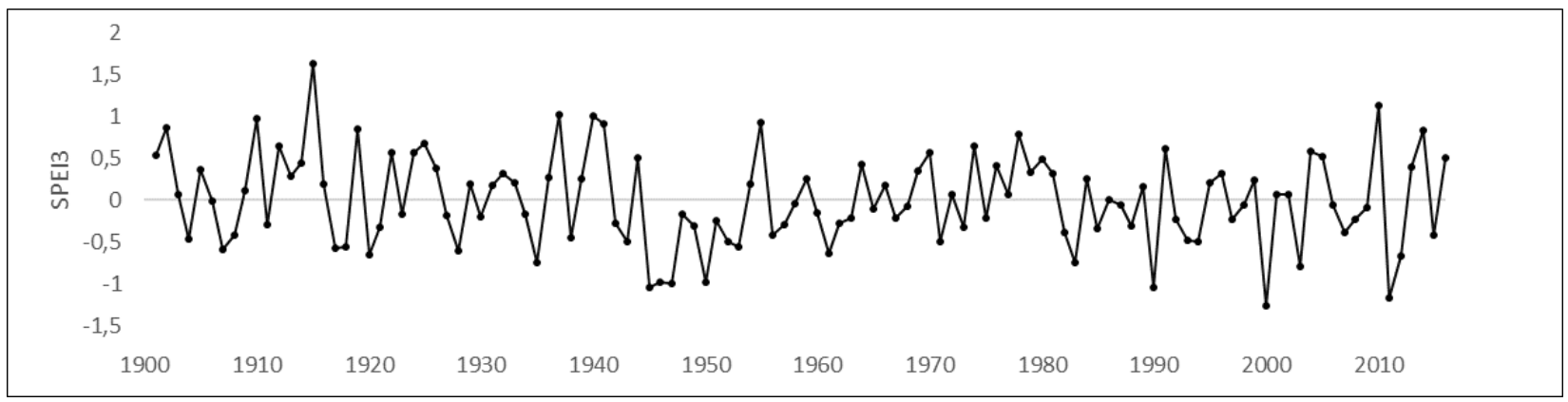


Fig. 2 Tree-ring width chronologies (a) and age-aligned regional growth curves of the 15 sampled Serbian spruce sites (b). Thick and thin lines in (b) differentiate old and young sites.

a)

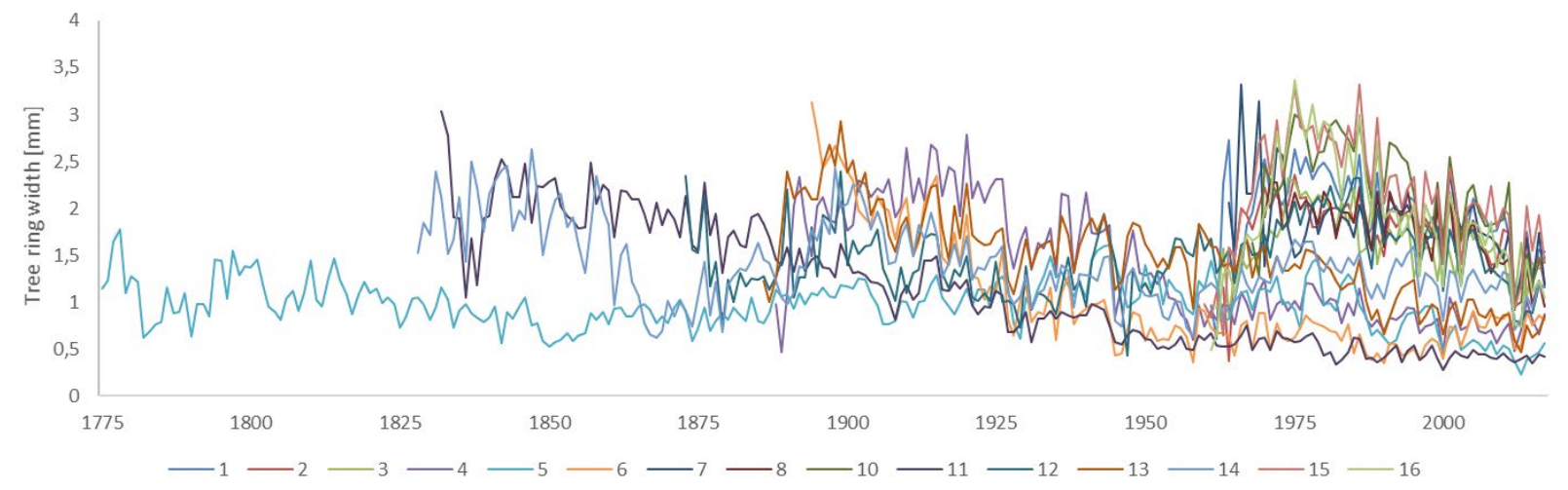

b)

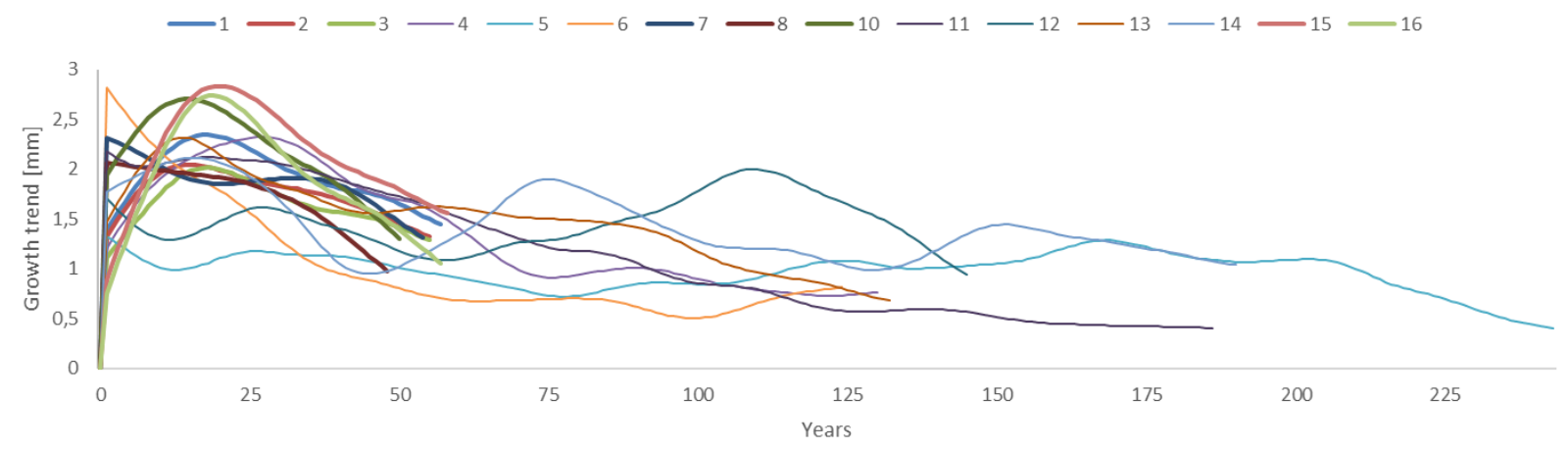


411 Fig. 3: Correlation matrix among the ring-width site chronologies

412

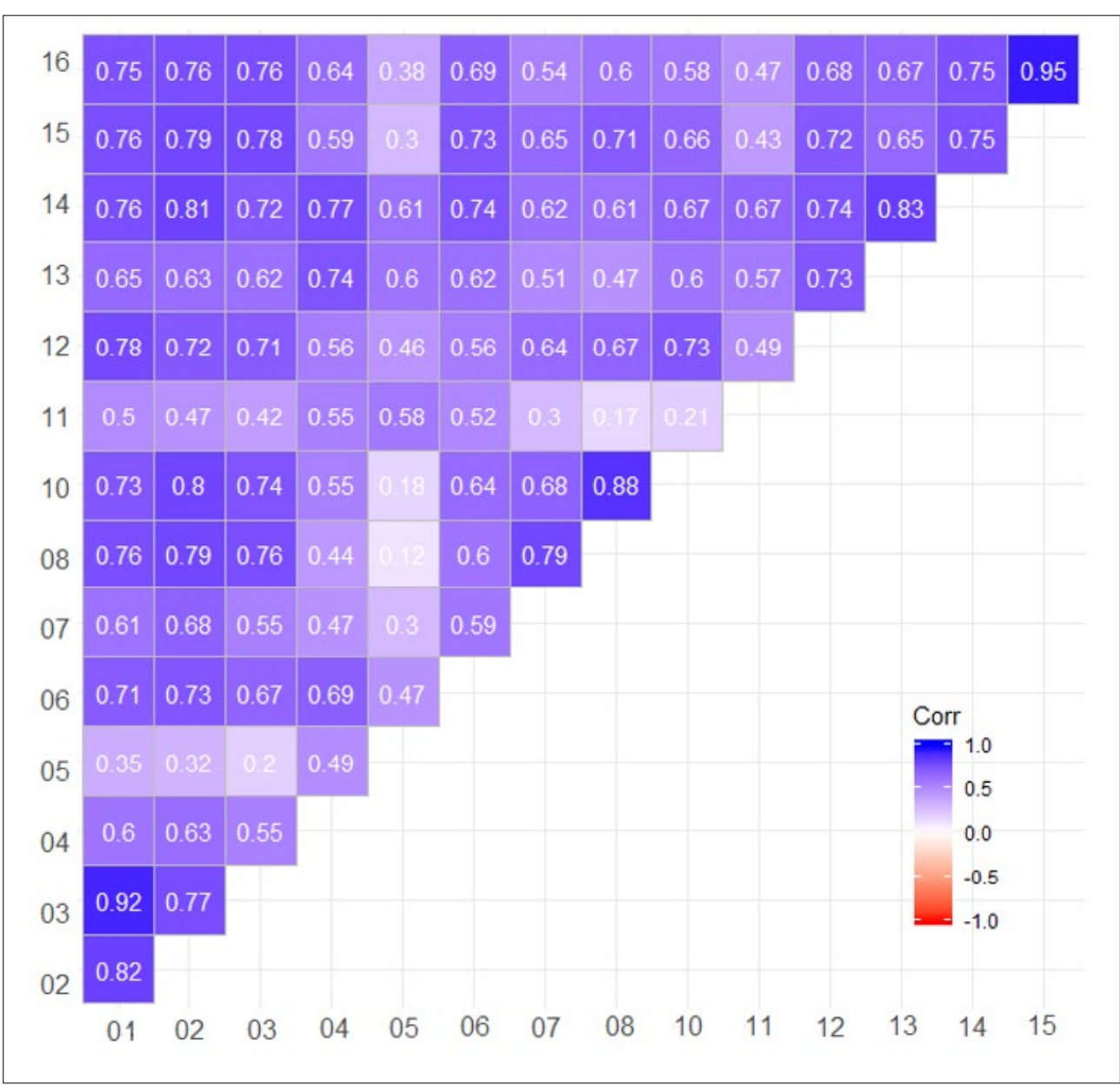

413

414

415 
Fig. 4 Climate growth relationships. a) Bootstrapped climate correlation for the period 1974-2016 for the species for the composite of the 10-years detrended chronologies with precipitation sum (blue), monthly mean temperature (red) and drought index SPEI3 (yellow). JJA indicates the summer mean correlation (June, July and August). Dashed horizontal lines represent the threshold of significance $(p<0.05)$. b) Moving window correlation ( 25 years wide) of climate-growth responses over the period 1906-2016 for the species for the composite of the 10-years detrended chronologies. Climate parameter are precipitation, temperature and SPEI3. Asterisk indicates significance $(p<0.05)$. $c)$ Climate-growth responses for each individual site chronologies over the period 1974-2016 for the strongest climatic signal obtained in the analyses (SPEI3 in August). Dashed horizontal lines represent the threshold of significance $(p<0.05)$. Site are ordered on their mean elevation and vertical line separate the results for elevation classes (800-1000, $1000-1200$ and $1200-1500 \mathrm{~m}$ ).

426

a)

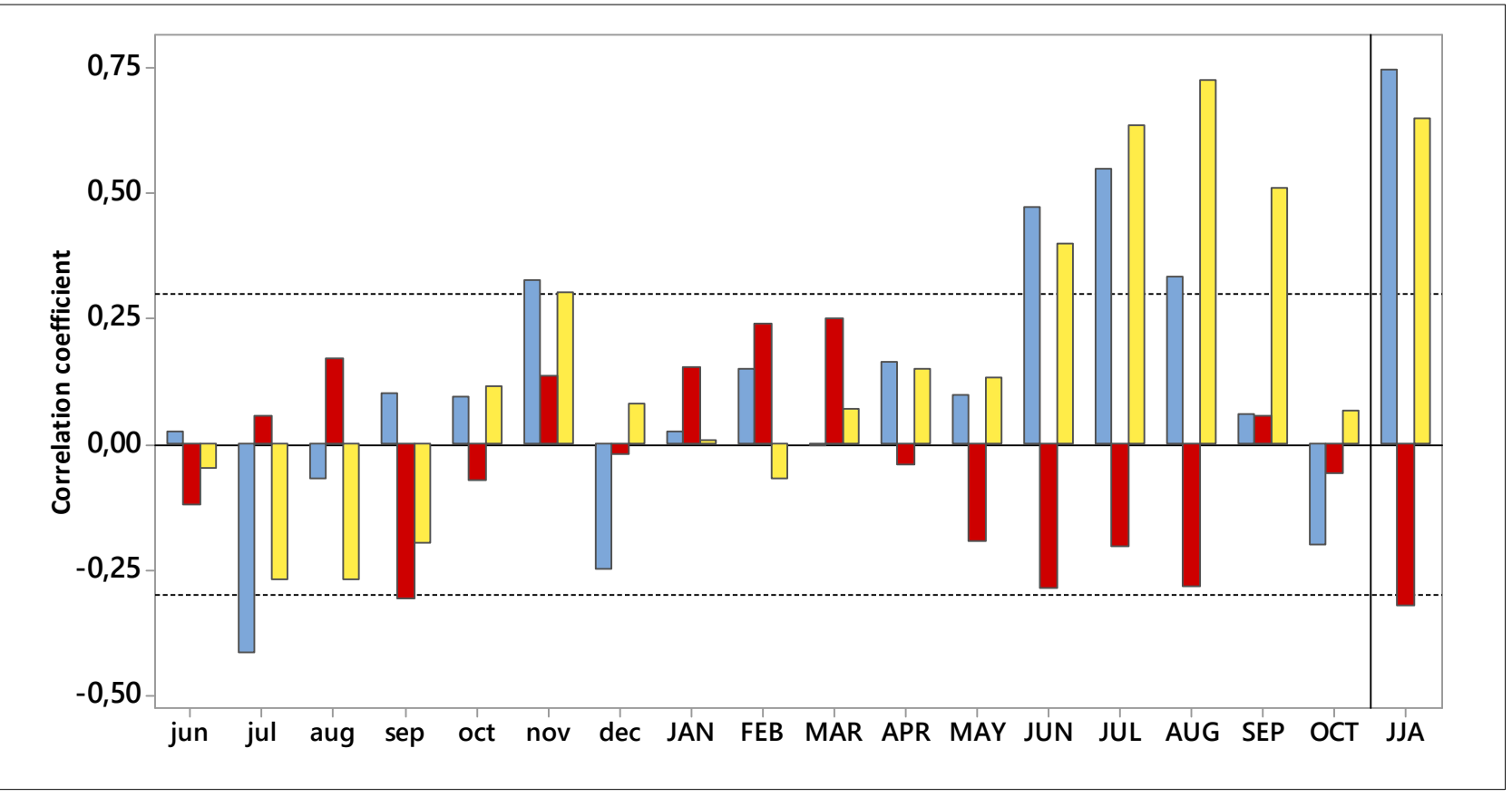




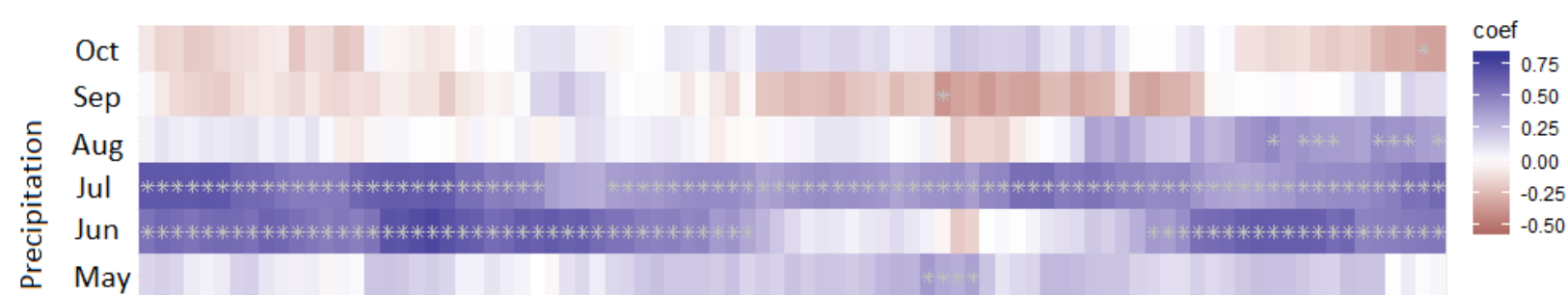

Apr

Mar

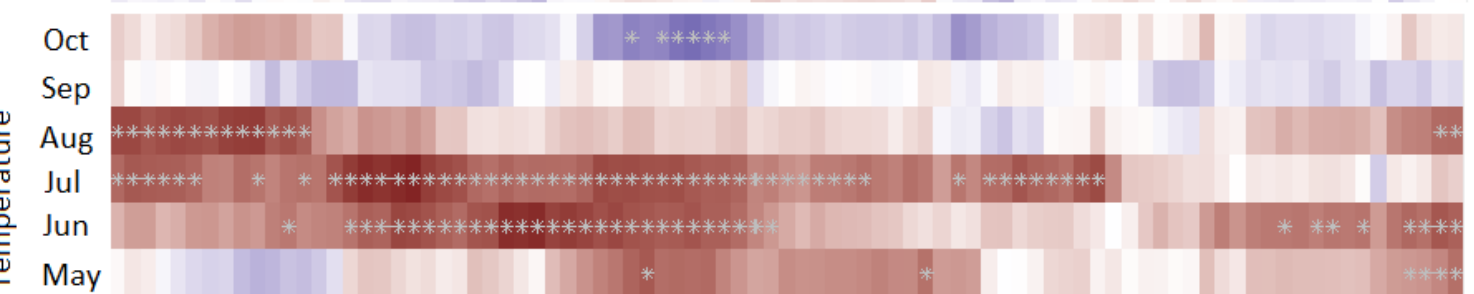

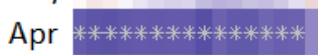

Mar

Oct

Sep

Aug $* * * * * * * * * * * * * * * * * * * * * * * * * * * * * * * * * * * * * * *)$

向 Jul $* * * * * * * * * * * * * * * * * * * * * * * * * * * * * * * * * * * * * * * * * * * * * * * * *)+* * * * * * * * * * * * * * * * * * * * * * * * * * * * * * *)$ के Ju

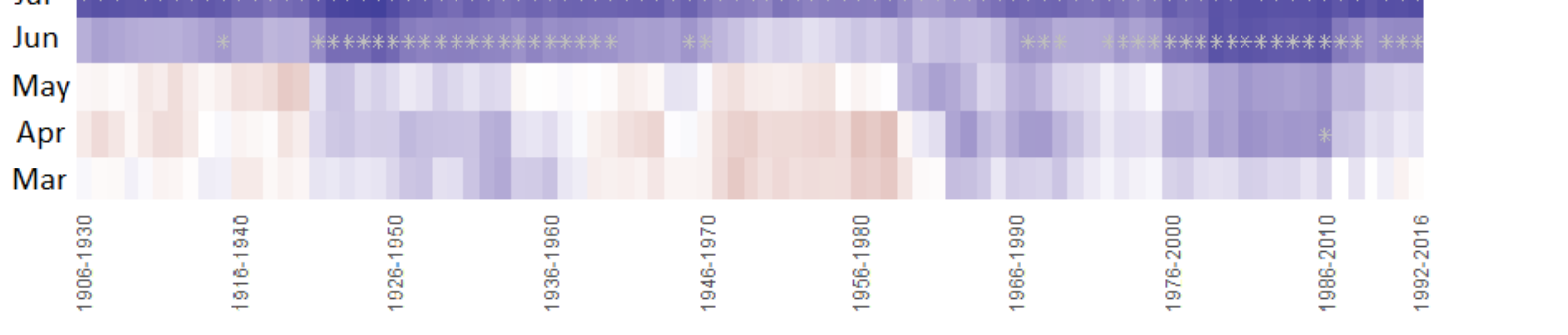

c)

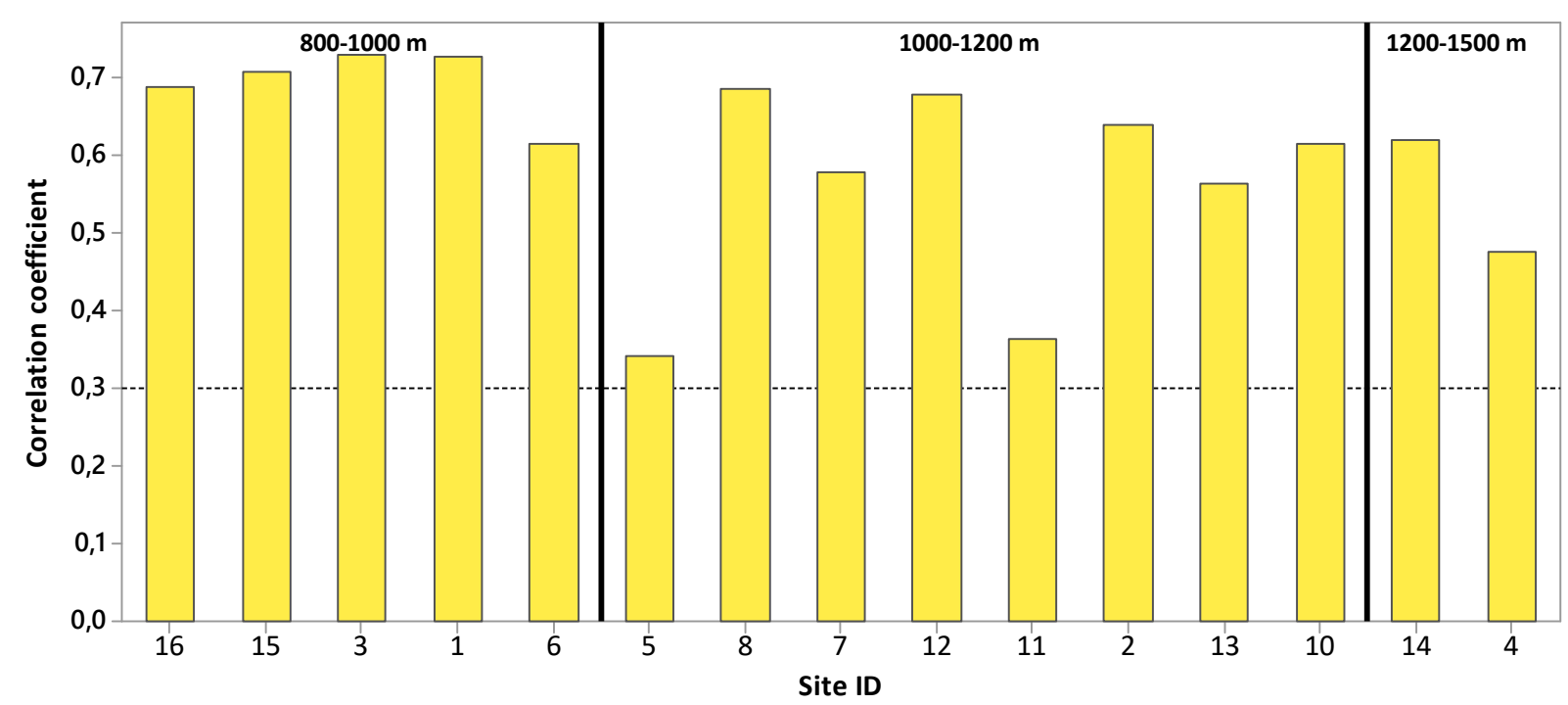


Fig. 5 Box plots representing the three resilience components of Llorets et al. (2011) resistance, recovery, resilience of the individual trees grouped per elevation (a) and age (b) as a response to the drought year 2012 . $L=$ 800 to $1000 \mathrm{~m}$ asl., $\mathrm{M}=1000$ to $1200 \mathrm{~m}$ asl., and $\mathrm{H}=1200$ to $1500 \mathrm{~m}$ asl.; $\mathrm{Y}<80$ years, $\mathrm{M}=81$ to 160 years, and $\mathrm{O}$ > 161 years). The horizontal dashed line indicates the value 1 , indicating no changes with respect to the reference.

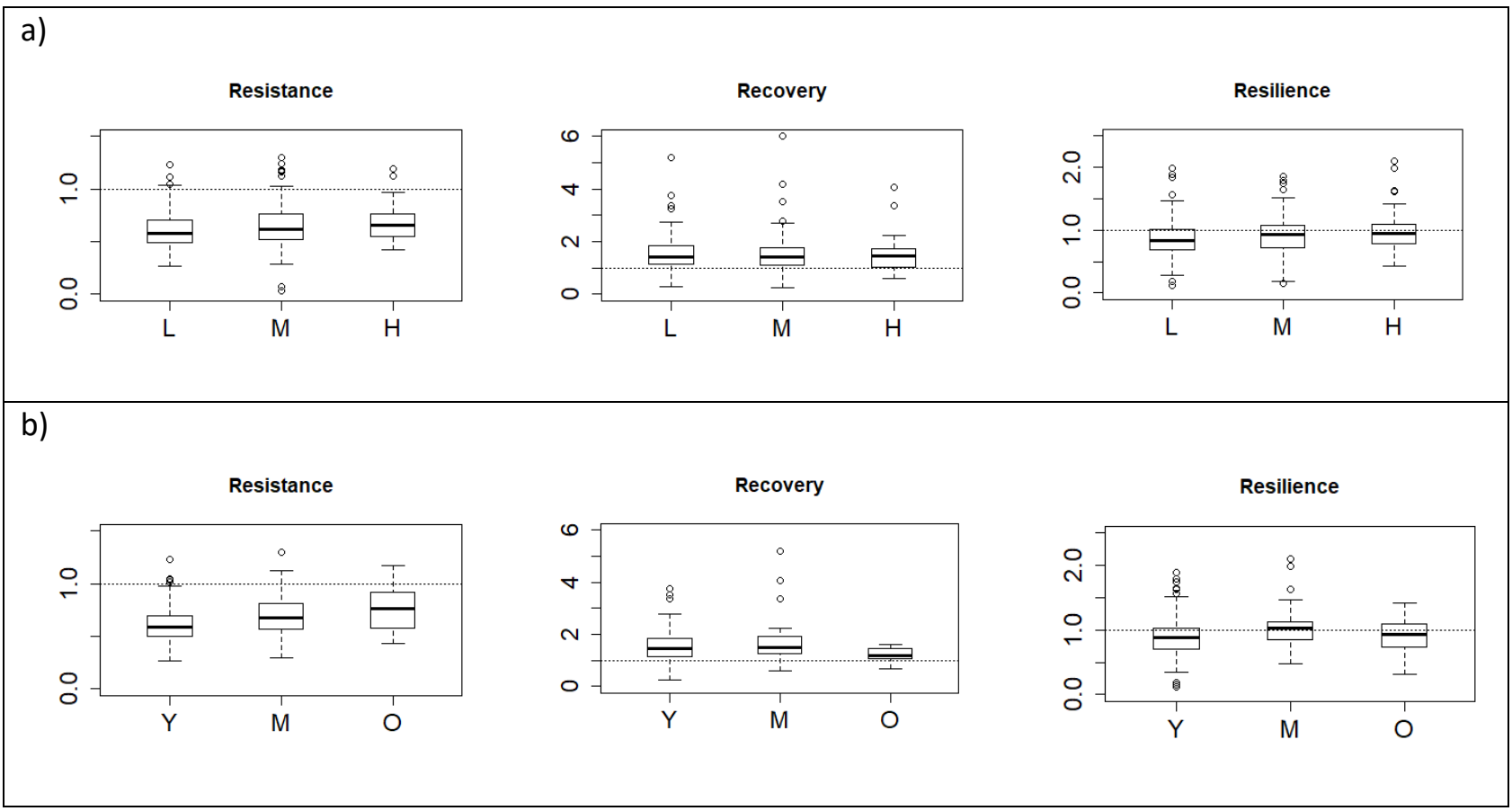

